\title{
Hypoxia-inducible factors enhance glutamate signaling in cancer cells
}

\author{
Hongxia Hu1,2,3, Naoharu Takano ${ }^{2,3}$, Lisha Xiang ${ }^{2,3,4}$, Daniele M. Gilkes ${ }^{2,3}$, Weibo \\ Luo $^{2,3,5}$ and Gregg L. Semenza $2,3,5,6$ \\ ${ }^{1}$ Predoctoral Training Program in Human Genetics, Johns Hopkins University School of Medicine, Baltimore, MD \\ ${ }^{2}$ McKusick-Nathans Institute of Genetic Medicine, Johns Hopkins University School of Medicine, Baltimore, MD \\ ${ }^{3}$ Vascular Program, Institute for Cell Engineering, Johns Hopkins University School of Medicine, Baltimore, MD \\ ${ }^{4}$ Department of Oncology and Southwest Cancer Center, Southwest Hospital, Third Military Medical University, Chongqing, \\ China \\ ${ }^{5}$ Department of Biological Chemistry, Johns Hopkins University School of Medicine, Baltimore, MD \\ ${ }^{6}$ Departments of Medicine, Oncology, Pediatrics, Radiation Oncology, Johns Hopkins University School of Medicine, Baltimore, \\ MD
}

Correspondence to: Gregg L. Semenza, email: gsemenza@jhmi.edu

Keywords:AMPA receptor, clear cell renal carcinoma, hepatocellular carcinoma, HIF-1

Received: October 01,2014 Accepted: October 15, $2014 \quad$ Published: October 15, 2014

This is an open-access article distributed under the terms of the Creative Commons Attribution License, which permits unrestricted use, distribution, and reproduction in any medium, provided the original author and source are credited.

\section{ABSTRACT}

Signaling through glutamate receptors has been reported in human cancers, but the molecular mechanisms are not fully delineated. We report that in hepatocellular carcinoma and clear cell renal carcinoma cells, increased activity of hypoxia-inducible factors (HIFs) due to hypoxia or VHL loss-of-function, respectively, augmented release of glutamate, which was mediated by HIF-dependent expression of the SLC1A1 and SLC1A3 genes encoding glutamate transporters. In addition, HIFs coordinately regulated expression of the GRIA2 and GRIA3 genes, which encode glutamate receptors. Binding of glutamate to its receptors activated SRC family kinases and downstream pathways, which stimulated cancer cell proliferation, apoptosis resistance, migration and invasion in different cancer cell lines. Thus, coordinate regulation of glutamate transporters and receptors by HIFs was sufficient to activate key signal transduction pathways that promote cancer progression.

\section{INTRODUCTION}

Hypoxia-inducible factors (HIFs) are transcription factors that mediate adaptive responses to reduced oxygen availability. HIFs are heterodimers, composed of an oxygen-regulated HIF- $1 \alpha$ or HIF- $2 \alpha$ subunit and a constitutively expressed HIF-1 $\beta$ subunit, that bind to the consensus DNA sequence 5'-RCGTG-3', which is embedded within hypoxia response elements (HREs) in target genes [1]. Proline residues $\mathrm{Pro}^{402}$ and $\mathrm{Pro}^{564}$ of human HIF-1 $\alpha\left(\right.$ Pro $^{405}$ and Pro $^{531}$ of HIF- $\left.2 \alpha\right)$ are subjected to $\mathrm{O}_{2}$ dependent hydroxylation by prolyl hydroxylase domain proteins (PHDs) [2-4]. This modification is required for interaction with the von Hippel-Lindau tumor suppressor protein (VHL), which is the substratespecific component of an E3 ubiquitin ligase that targets hydroxylated HIF- $1 \alpha$ or HIF- $2 \alpha$ for ubiquitination and subsequent proteasomal degradation [4].

HIFs have been implicated in many developmental, physiological and pathophysiological processes $[3,5,6]$. HIFs play key roles in many critical aspects of cancer biology, including metabolic reprogramming, proliferation, survival, stem cell maintenance, angiogenesis, epithelialmesenchymal transition, immune evasion, invasion, metastasis, and resistance to chemotherapy and radiation therapy [7]. Regions of intratumoral hypoxia are present in many solid cancers, leading to induction of HIF activity [8]. In addition, oncogene gain-of-function or tumor suppressor gene loss-of-function also stimulates increased HIF activity in cancer [9]. The most notable example of a genetic alteration driving HIF activity is in clear cell renal cell carcinoma (ccRCC), which has a high 
incidence of VHL loss-of-function due to either mutation or epigenetic silencing, which leads to high HIF activity even under non-hypoxic conditions [10]. High HIF-1 $\alpha$ or HIF-2 $\alpha$ abundance in the diagnostic biopsy is associated with metastasis, treatment failure, and patient mortality in many types of cancer [7, 9].

Glutamate is the primary excitatory neurotransmitter of the central nervous system (CNS). However, glutamate signaling has been implicated in various non-excitable tissues, as well as in several diseases including cancer [11]. In glioma, glutamate secretion by cancer cells induces excitotoxic death of neighboring neurons, thereby facilitating tumor growth and invasion $[12,13]$. Glutamate antagonists inhibit the proliferation and migration of glioma and other cancer cell types [14]. Glutamate acts on metabotropic or ionotropic cell surface receptors. The metabotropic receptors are $\mathrm{G}$ protein-coupled receptors that are encoded by the GRM1-8 genes. The ionotropic receptors mainly include three subclasses: $N$-methyl-Daspartate (NMDA) receptors, which are encoded by the GRIN1, GRIN2A-D, and GRIN3A-B genes; $\alpha$-amino-3hydroxy-5-methyl-4-isoxazolepropionic acid (AMPA) receptors, which are encoded by the GRIA1-4 genes; and kainate receptors, which are encoded by the GRIK1-5 genes [15].

Glutamate receptors have been implicated in several different types of cancer. Insertional mutagenesis of $\mathrm{Grm} 1$ or melanocyte-specific overexpression of Grm 1 or Grm5 leads to melanoma in transgenic mouse models [16, 17]. The expression of all 24 genes encoding glutamate receptor subunits has been detected at the mRNA level in cancer cell lines [18]. Molecular and biochemical studies of glutamate receptors have demonstrated their roles in various cancer types [19-22]. High-throughput genomic studies have identified GRM1, GRM3, GRM4, GRM8 and GRIN2A as susceptibility genes in non-small-cell lung cancer (NSCLC), melanoma, osteosarcoma, and bladder cancer [23-27]. In contrast, GRIK2, which is the gene most frequently involved in chromosome $6 \mathrm{q}$ deletions in acute lymphocytic leukemia, is regarded as a tumor suppressor gene [28]. Additionally, hypermethylation of GRIK1, GRIK2, GRIN2A and GRIN2B has been reported in ccRCC, gastric cancer, colon cancer, esophageal squamous cell carcinoma and NSCLC [29-34]. Thus, the effect of gain or loss of glutamate receptor function varies in different cancers.

In the present study, we demonstrated that HIF activity, induced by hypoxia or VHL loss-of-function in hepatocellular and renal carcinoma cells, respectively, mediated the coordinate transcription of multiple genes encoding glutamate transporters and glutamate receptors, which resulted in activation of signal transduction pathways that stimulated cancer cell proliferation, survival, or migration and invasion. Our results demonstrate that HIFs mediate glutamate signaling that promotes cancer progression.

\section{RESULTS}

\section{Hypoxia induces glutamate release and the expression of genes encoding glutamate transporters in Hep3B cells}

Human glioma, mouse melanoma, rat prostate cancer, and human breast cancer cells have been shown to release glutamate $[12,35]$. Because high concentrations of extracellular glutamate also accumulate in response to cerebral ischemia [36], we hypothesized that hypoxia may induce glutamate release from cancer cells. To test this, we maintained human hepatocellular carcinoma Hep3B cells at $20 \% \mathrm{O}_{2}$ or exposed the cells to $1 \% \mathrm{O}_{2}$ for 24 or $48 \mathrm{~h}$. We observed a time-dependent increase of extracellular glutamate in the media of cells exposed to hypoxia, as compared to cells maintained at $20 \% \mathrm{O}_{2}$ (Fig. $1 \mathrm{~A})$, indicating that reduced oxygen availability triggers increased glutamate release from Hep3B cells.

There are several molecular mechanisms by which glutamate release is mediated: vesicular glutamate transporters (encoded by genes $S L C 17 A 6-8$ ); the cystineglutamate antiporter system $\mathrm{x}_{\mathrm{c}}^{-}$(encoded by SLC7A11 and $S L C 3 A 2$ ); and the membrane glutamate transporters EAAT3, EAAT2, EAAT1, EAAT4, and EAAT5 (encoded by $S L C 1 A 1, S L C 1 A 2, S L C 1 A 3, S L C 1 A 6$, and SLC1A7). Reverse transcription and quantitative real-time PCR (RT-qPCR) analysis of Hep3B cells exposed to $20 \%$ or $1 \% \mathrm{O}_{2}$ for $24 \mathrm{~h}$ revealed that the abundance of SLC1A1 and SLC1A3 mRNA, but not that of mRNAs encoding other glutamate transporters, was significantly induced by hypoxia (Fig. 1B and Fig. S1A). Hypoxia did not induce SLC1A1 and SLC1A3 mRNA in two breast cancer cell lines (Fig. S1B-C). SLC1A1 and SLC1A3 mRNA expression was also increased when Hep3B cells were treated with $100 \mu \mathrm{M}$ dimethyloxalylglycine (DMOG), which inhibits PHD activity (Fig. 1C).

\section{HIFs mediate SLC1A1 and SLC1A3 gene expression in hypoxic Hep3B cells}

To determine whether HIF-1 or HIF-2 was directly responsible for the hypoxia-induced expression of SLC1A1 and $S L C 1 A 3$, Hep3B cells were stably transfected with vectors encoding: a short hairpin RNA (shRNA) that was non-targeting $(\operatorname{shNT})$; shRNA targeting HIF-1 $\alpha(\operatorname{sh} 1 \alpha)$ or HIF- $2 \alpha(\operatorname{sh} 2 \alpha)$; or shRNAs targeting both HIF-1 $\alpha$ and HIF-2 $\alpha(\operatorname{sh} 1 \alpha / 2 \alpha)$. Analysis of SLC1A1 and SLC1A3 mRNA (Fig. 1D) and protein (Fig.1E) revealed that hypoxia-induced expression was abrogated when HIF-1 $\alpha$, HIF-2 $\alpha$, or both were knocked down in Hep3B cells. The effects of these shRNAs on their targets were confirmed by immunoblot assays (Fig.1E).

To examine whether $S L C 1 A 3$ was a direct HIF 
target gene, we performed chromatin immunoprecipitation (ChIP) assays with primers flanking HIF consensus binding site sequences along the gene. One site located 2 $\mathrm{kb}$ downstream of the SLC1A3 gene (gray oval in Fig. 1F, top) was enriched by immunoprecipitation of chromatin from hypoxic cells with HIF-1 $\alpha$, HIF-2 $\alpha$ (Fig. 1G), or HIF-1 $\beta$ (Fig. 1H) antibody. To test whether this HIFbinding site was embedded in an HRE, a 55-bp wild-type (WT) sequence spanning the site (Fig. 1F, bottom, HIF binding site is underscored) was inserted into the firefly luciferase reporter plasmid pGL2-promoter. Hep3B cells co-transfected with this SLC1A3 HRE reporter and a control pSV-Renilla luciferase reporter were exposed to $20 \%$ or $1 \% \mathrm{O}_{2}$. The ratio of firefly:Renilla luciferase activity increased with hypoxic exposure. Mutation of the HIF binding site in the SLC1A3 HRE (5'-ACGTG-3' to 5'-AAAAG-3') significantly impaired hypoxia-induced luciferase activity (Fig. 1I). Taken together, these results suggested that HIF-dependent increases in SLC1A1 and SLC1A3 expression may contribute to increased efflux of glutamate from Hep3B cells under hypoxic conditions.

\section{Glutamate receptor signaling stimulates proliferation of hypoxic Hep3B cells}

Whereas the proliferation of most cells is inhibited by hypoxia, the proliferation of Hep3B cells was
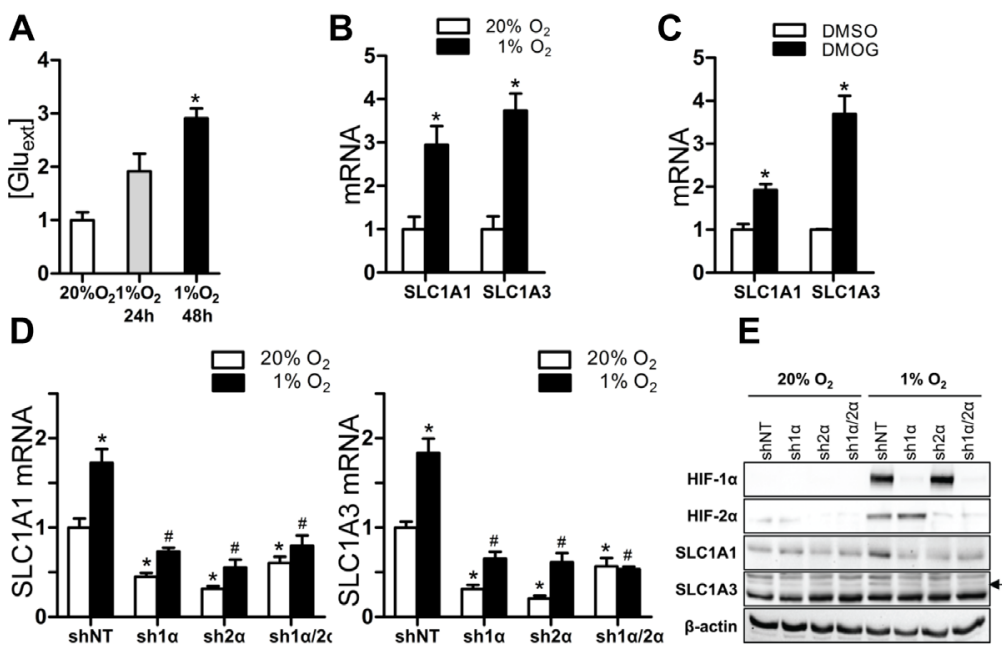

$\mathbf{F}$
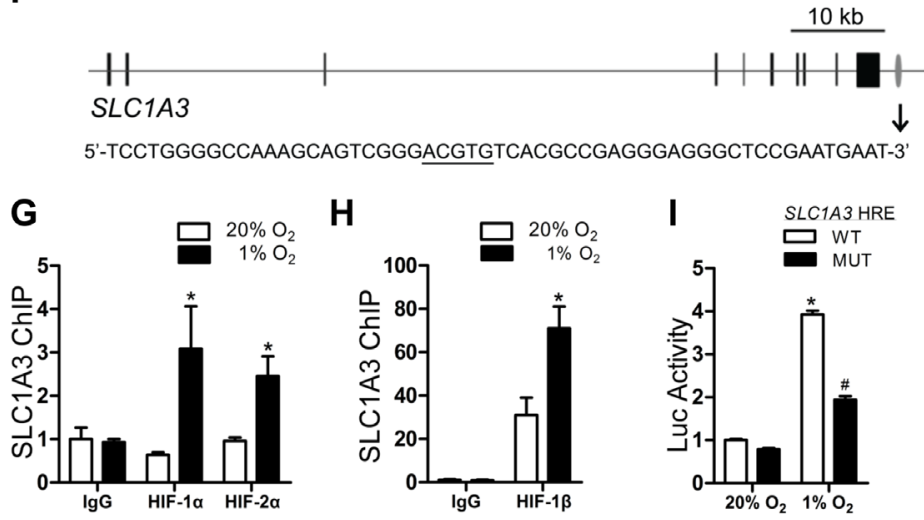

Figure 1: Glutamate release and transporter expression in Hep3B cells. (A) Cells were cultured for indicated time and glutamate concentration in medium was determined and normalized to $20 \% \mathrm{O}_{2} .{ }^{*} P<0.05$ vs $20 \% \mathrm{O}_{2}$, one-way ANOVA with Dunnett posttest. (B-C) Cells were exposed to $20 \%$ or $1 \% \mathrm{O}_{2}$ (B), or to vehicle (DMSO) or DMOG (C) for $24 \mathrm{~h}$. mRNAs were analyzed by RT-qPCR and normalized to $20 \% \mathrm{O}_{2}$ or DMSO. ${ }^{*} P<0.05$ vs $20 \% \mathrm{O}_{2}$ or DMSO, Student's $t$ test. (D) mRNAs were analyzed in subclones expressing shRNA directed against HIF- $1 \alpha$, HIF- $2 \alpha$ or both that were exposed to $20 \%$ or $1 \% \mathrm{O}_{2}$ for 24 h. ${ }^{*} P<0.05$ vs shNT at $20 \%$ O ${ }_{2}{ }^{\#} P<0.05$ vs shNT at $1 \% \mathrm{O}_{2}$; two-way ANOVA/Bonferroni post-test. (E) Immunoblot assays were performed using lysates from subclones exposed to $20 \%$ or $1 \% \mathrm{O}_{2}$; arrow indicates the SLC1A3-specific band. (F) SLC1A3 exons and HRE are indicated by black bars and grey oval, respectively. HRE nucleotide sequence is shown below. (G-H) Cells were exposed to $20 \%$ or $1 \% \mathrm{O}_{2}$ for $24 \mathrm{~h}$. ChIP assays were performed using IgG or indicated antibody. ${ }^{*} P<0.05$ vs $20 \% \mathrm{O}_{2}$, ANOVA with Bonferroni post-test. (I) Luciferase (Luc) activity was determined in cells co-transfected with pSV-Renilla and a firefly luciferase reporter containing the wild-type (WT) or mutant SLC1A3 hypoxia response element (HRE). ${ }^{*} P<0.05$ vs WT at $20 \% \mathrm{O}_{2},{ }^{\sharp} P<0.05$ vs WT at $1 \% \mathrm{O}_{2}$, ANOVA with Bonferroni post-test. Data are mean \pm SEM or a representative blot from $\geq 3$ experiments. 
significantly increased under hypoxic conditions (Fig. 2A). Since the mitogen-activated protein kinase (MAPK) signaling cascade leading to the phosphorylation/ activation of ERK1/2 is a major pathway for extracellular signal-induced cell proliferation, we examined the phosphorylation of ERK1/2 in cells exposed to vehicle or antagonists of various classes of glutamate receptors, including the NMDA receptor antagonist MK-801 and the AMPA receptor antagonist GYKI 52466. Phosphorylation of ERK1/2 was increased in vehicle-treated cells exposed to $1 \% \mathrm{O}_{2}$. Hypoxia-induced ERK1/2 phosphorylation was inhibited by GYKI 52466, but not by MK-801. ERK1/2 is activated by the upstream MAPK/ERK kinase (MEK) and the MEK inhibitor U0126 completely abolished phosphorylation of ERK1/2 (Fig. 2B) and inhibited cell proliferation under both $20 \%$ and $1 \% \mathrm{O}_{2}$ (Fig. 2C). In contrast, incubation of Hep3B cells with GYKI 52466 inhibited phosphorylation of ERK1/2 and cell proliferation specifically under $1 \% \mathrm{O}_{2}$ (Fig. 2D). Although MK-801 had no effect on hypoxia-induced ERK1/2 phosphorylation, it did reduce cell proliferation (Fig. S2A), which is consistent with a previous report that MK-801 blocks growth of hepatocellular carcinoma cells by increasing FOXO activity [37]. Taken together, these results suggest that glutamate released by hypoxic Hep3B cells binds to AMPA receptors and stimulates MEK-ERK signaling, leading to increased proliferation.

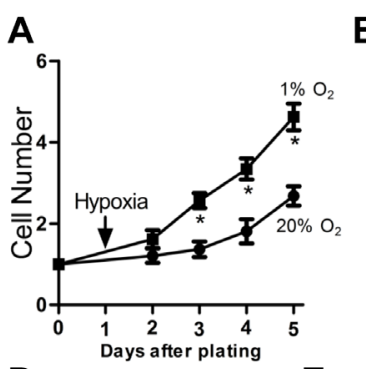

D

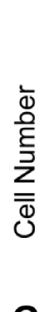

$\mathbf{G}$

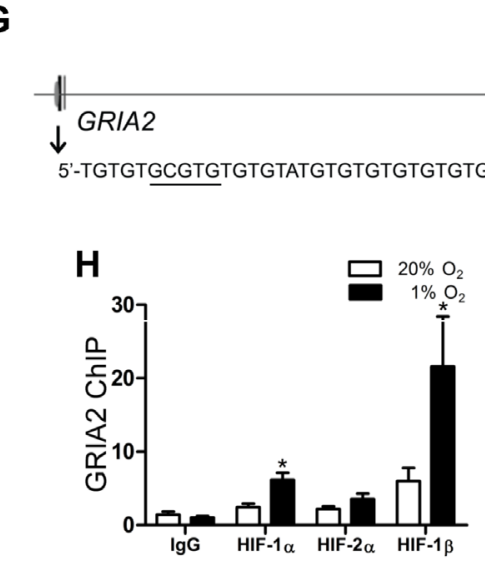

B

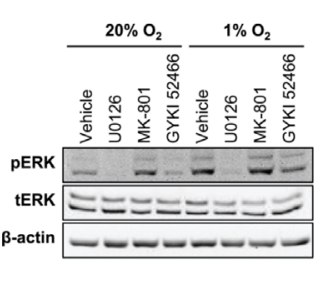

C

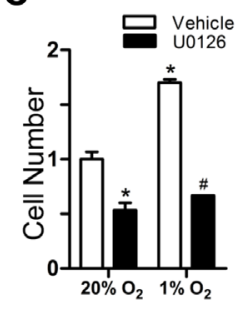

E
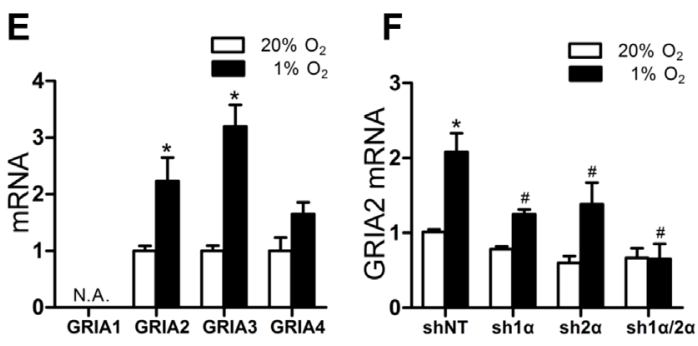
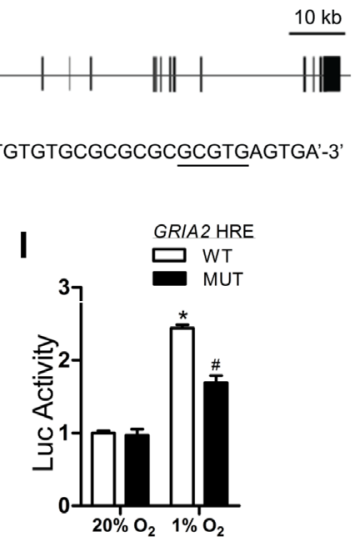

Figure 2: Glutamate receptor signaling and proliferation of Hep3B cells. (A) Cells were exposed to $20 \%$ or $1 \%$ O and counted. ${ }^{*} \mathrm{P}<0.05$ vs $20 \% \mathrm{O}_{2}$, ANOVA with Bonferroni post-test. (B) Immunoblot analysis was performed on cells exposed to $20 \%$ or $1 \% \mathrm{O}_{2}+$ vehicle, U0126, MK-801, or GYKI 52466 for $24 \mathrm{~h}$. (C-D) Cells were exposed to $20 \%$ or $1 \% \mathrm{O}_{2}+$ vehicle or either GYKI 52466 (C) or U0126 (D) for $96 \mathrm{~h}$ and counted. ${ }^{*} P<0.05$ vs vehicle- $20 \% \mathrm{O}_{2},{ }^{\sharp} P<0.05$ vs vehicle- $1 \% \mathrm{O}_{2}$, ANOVA with Bonferroni post-test. (E) Cells were exposed to $20 \%$ or $1 \% \mathrm{O}$ for $24 \mathrm{~h}$ and mRNAs were analyzed. ${ }^{*} P<0.05$ vs $20 \%$, Student's $t$ test. (F) GRIA2 mRNA abundance was analyzed in shRNA-expressing subclones exposed to $20 \%$ or $1 \% \mathrm{O}_{2}$ for $24 \mathrm{~h} .{ }^{*} P<0.05$ vs shNT- $20 \% \mathrm{O}_{2}$; ${ }^{\#} P<0.05$ vs shNT-1\% $\mathrm{O}_{2}$, twoway ANOVA with Bonferroni post-test. (G) GRIA2 exons and HRE are indicated by black bars and grey oval, respectively; HRE sequence is shown below. $(\mathrm{H})$ ChIP assays of cells that were exposed to $20 \%$ or $1 \% \mathrm{O}_{2}$ for $24 \mathrm{~h}$. ${ }^{*} P<0.05$ vs $20 \%$, ANOVA with Bonferroni post-test. (I) Luciferase (Luc) activity was determined in cells co-transfected with pSV-Renilla and a firefly luciferase reporter containing the wildtype or mutant $S L C 1 A 3$ HRE. ${ }^{*} P<0.05$ vs WT- $20 \% \mathrm{O}_{2},{ }^{\#} P<0.05$ vs WT- $1 \% \mathrm{O}_{2}$, ANOVA with Bonferroni post-test. Data are mean \pm SEM or a representative blot from $\geq 3$ experiments. 


\section{HIF-1 mediates hypoxia-induced expression of glutamate receptors}

AMPA receptors are homotetramers or heterotetramers composed of subunits GluR1 to GluR4, which are encoded by GRIA1 to GRIA4. AMPA receptors are responsible for the vast majority of fast excitatory synaptic transmission within the mammalian central nervous system [38]. Expression of GRIA2 and GRIA3 mRNA was induced by hypoxia in Hep3B cells (Fig.
2E) but not in two breast cancer cell lines (Fig. S2B-C). Increased GRIA2 and GRIA3 protein expression was also induced by hypoxia (Fig. S2D). Hypoxic induction of GRIA2 and GRIA3 mRNA expression was significantly inhibited when expression of HIF-1 $\alpha$ or HIF- $2 \alpha$, and especially when expression of both HIF-1 $\alpha$ and HIF-2 $\alpha$, was knocked down in Hep3B cells (Fig. 2F and Fig. S2E). ChIP assays revealed that a DNA sequence encompassing two copies of 5'-GCGTG-3', with one copy at -26 nt and the other copy at $+15 \mathrm{nt}$ relative to the GRIA2 transcription start site (Fig. 2G), was enriched by immunoprecipitation
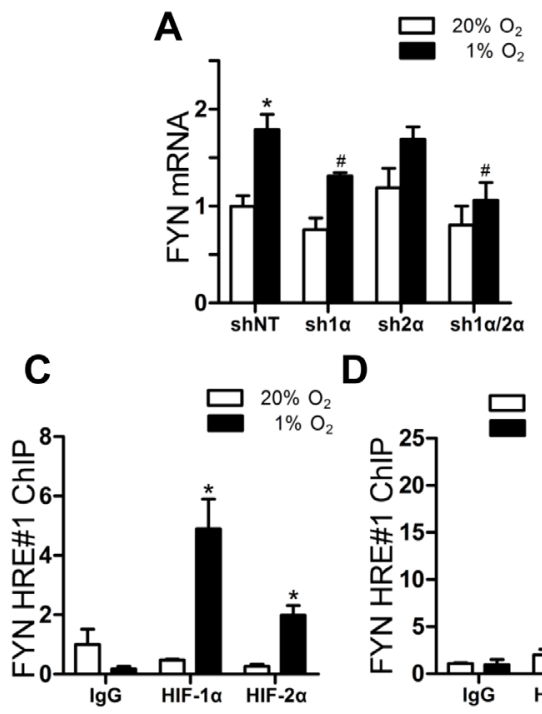

$\mathbf{F}$

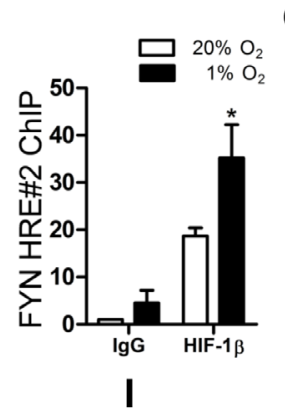

D

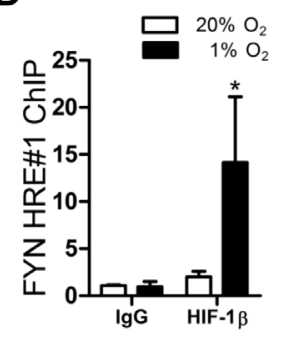

B

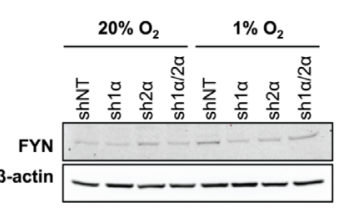

E

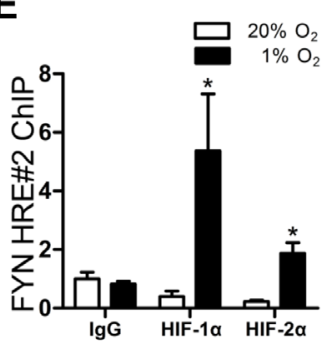

$\mathrm{H}$

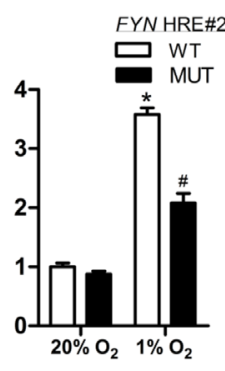

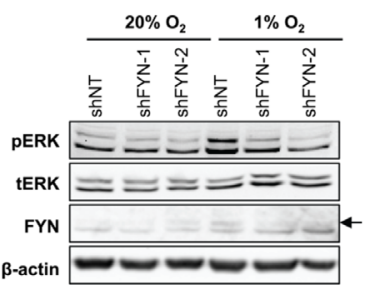

G

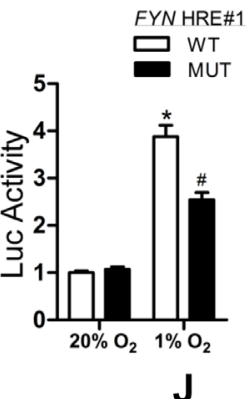

J

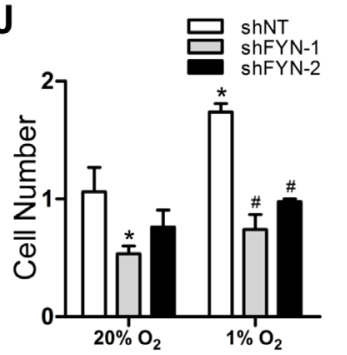

Figure 3: HIF-dependent FYN signaling to ERK in hypoxic Hep3B cells. (A) FYN mRNA levels were analyzed in shRNAexpressing subclones exposed to $20 \%$ or $1 \% \mathrm{O}_{2} .{ }^{*} P<0.05$ vs shNT- $20 \% \mathrm{O}_{2},{ }^{\#} P<0.05$ vs shNT- $1 \% \mathrm{O}_{2}$, two-way ANOVA with Bonferroni post-test. (B) Immunoblot analysis was performed on shRNA-expressing subclones cultured at $20 \%$ or $1 \% \mathrm{O}_{2}$. (C-F) ChIP assays were performed in cells exposed to $20 \%$ or $1 \% \mathrm{O}$ using primers flanking $F Y N$ HRE\#1 (C-D) or primers flanking $F Y N$ HRE\#2 (E-F). ${ }^{*} P<0.05$ vs $20 \% \mathrm{O}_{2}$, ANOVA with Bonferroni post-test. $(\mathrm{G}-\mathrm{H})$ Luciferase activity was determined in cells expressing a reporter containing HRE\#1 (G) or HRE\#2 (H). ${ }^{*} P<0.05$ vs WT-20\% $\mathrm{O}_{2}, \# P<0.05$ vs WT- $1 \% \mathrm{O}_{2}$, ANOVA with Bonferroni post-test. (I) Immunoblot assays of control (shNT) and FYN knockdown (shFYN-1 and shFYN-2) subclones exposed to $20 \%$ or $1 \% \mathrm{O}_{2}$ for $24 \mathrm{~h}$; arrow indicates FYN-specific band. (J) Cells were incubated in $20 \%$ or $1 \% \mathrm{O}_{2}$ for $72 \mathrm{~h}$ and counted. ${ }^{*} P<0.05$ vs shNT- $20 \% \mathrm{O}_{2},{ }^{*} P<0.05$ vs shNT-1\% O 2 , ANOVA with Bonferroni post-test. Data are mean \pm SEM or a representative blot from $\geq 3$ experiments. 
of chromatin from hypoxic Hep3B cells with HIF-1 $\alpha$ or HIF-1 $\beta$ antibodies (Fig. 2H). A 55-bp WT sequence (Fig. 2G, bottom) spanning the HIF binding sites, or the same sequence with mutation of 5'-GCGTG-3' to 5'-GAAAG-3' (MUT), was inserted into pGL2-promoter. Hypoxia increased the ratio of firefly:Renilla luciferase to a greater extent in Hep3B cells coexpressing the GRIA2 HRE-WT reporter and pSV-Renilla compared to cells transfected with HRE-MUT (Figure 2I). Taken together, these results indicate that expression of GRIA2 and GRIA3 is induced by hypoxia in a HIF-dependent manner and that, at least in the case of GRIA2, this results from direct binding of HIF-1 to the target gene.

\section{FYN is a HIF-regulated functional intermediary between GRIA2/3 and ERK1/2}

The Src family tyrosine kinase LYN physically and functionally associates with AMPA receptors and is involved in the AMPA-receptor-mediated activation of MAPK signaling in primary cell cultures from the cerebellum [39]. Expression of another Src family member, FYN, is upregulated in ccRCC cell lines with HIF activation [40]. We investigated whether FYN expression was regulated by HIFs in Hep3B cells and whether it transduced signals from AMPA receptors

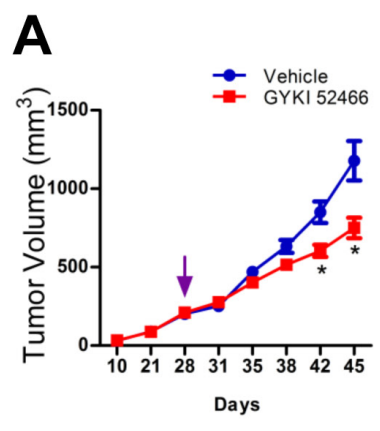

C

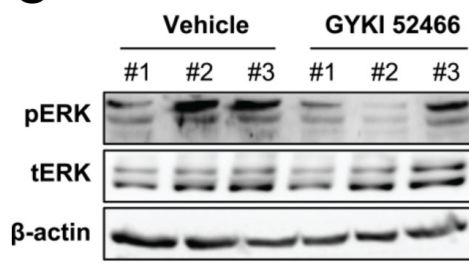

D

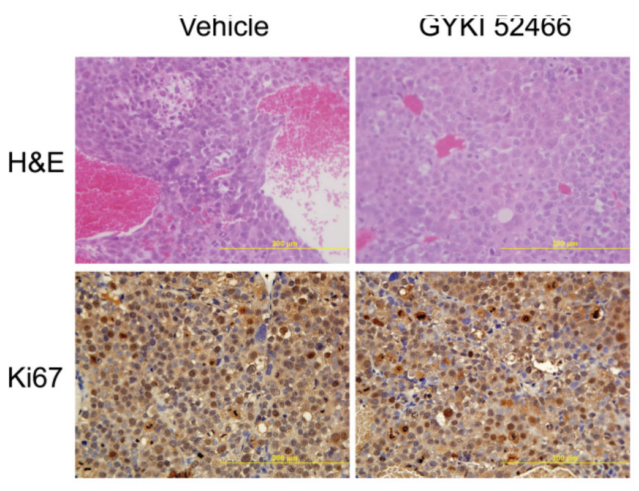

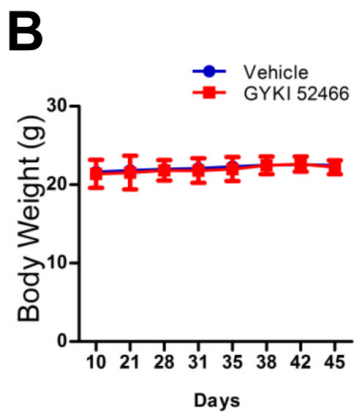

E

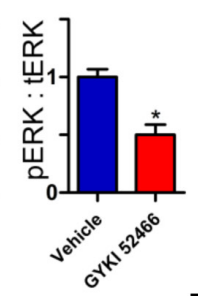

$\mathbf{F}$
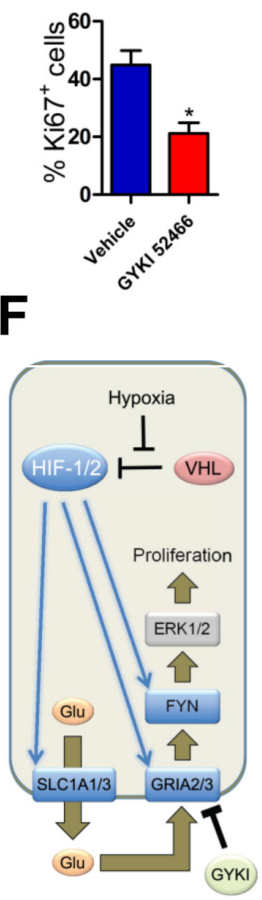

Figure 4: Glutamate receptor signaling in Hep3B tumor xenografts. (A-B) Mice with xenografts that reached $200 \mathrm{~mm}^{3}$ were treated with vehicle or GYKI 52466. Tumor volume (A) and body weight (B) were monitored. ${ }^{*} P<0.05$ vs vehicle, ANOVA/ Bonferroni post-test (mean $\pm \mathrm{SEM} ; \mathrm{n}=3$ mice per treatment). (C) Tumor lysates were subjected to immunoblot assays (left) and the ratio of phosphorylated:total ERK (pERK/tERK) was determined (right). ${ }^{*} P<0.05$ vs vehicle, Student's $t$ test (mean \pm SEM; $\mathrm{n}=3$ mice per treatment). (D) Tumor sections were stained with hematoxylin and eosin (upper panels) and Ki67 (lower panels). (E) The percentage of cells positively stained with Ki67 was quantified. ${ }^{*} P<0.05$ vs vehicle, Student's $t$ test (mean \pm SEM; $n=3$ mice per treatment). (F) The mechanisms and consequences of HIF-dependent glutamate signaling in hypoxic Hep3B cells are shown. 
Table 1: SLC1A1, SLC1A3, GRIA3 and FYN gene expression is correlated with the expression of known HIF target genes in clear cell renal cell carcinomas.

\begin{tabular}{|l|l|l|l|l|l|l|}
\hline Category & GENE & SLC1A1 & SLC1A3 & GRIA3 & FYN & PKM2 \\
\hline \multirow{5}{*}{ HIF Targets } & SLC2A1 & $*$ & $*$ & $*$ & $* * *$ & $*$ \\
\cline { 2 - 7 } & LDHA & $* * *$ & n.s. & $* *$ & $* * *$ & n.s. \\
\cline { 2 - 7 } & BNIP3 & $* * *$ & $n . s$. & $* *$ & $* * *$ & n.s. \\
\cline { 2 - 7 } & CA9 & $* * *$ & $* *$ & $* *$ & $* * *$ & $*$ \\
\cline { 2 - 7 } & SLC16A3 & $* * *$ & $* *$ & $* * *$ & $* * *$ & $*$ \\
\cline { 2 - 7 } & VEGFA & $* * *$ & $n . s$. & $* * *$ & $* * *$ & n.s. \\
\hline \multirow{2}{*}{ Non-HIF target } & RPL4 & $n . s$. & $n . s$. & $n . s$. & n.s. & n.s. \\
\hline
\end{tabular}

$* P<0.05, * * P<0.01, * * * P<0.001$, n.s., not significant, Pearson's correlation test of microarray data from The Cancer Genome Atlas (TCGA) dataset of 42 renal clear cell carcinomas.

to ERK. FYN mRNA (Fig. 3A) and protein (Fig. 3B) abundance was increased by hypoxia in the Hep3B subclone expressing a non-targeted control shRNA $(\mathrm{shNT})$, an increase that was abrogated in the HIF-1 $\alpha$ knockdown $(\operatorname{sh} 1 \alpha)$ and the HIF-1 $\alpha$ and HIF- $2 \alpha$ double knockdown $(\operatorname{sh} 1 \alpha / 2 \alpha)$ subclones, but not in the HIF-2 $\alpha$ knockdown $(\operatorname{sh} 2 \alpha)$ subclone. In contrast, the abundance of other SRC family kinases including SRC, LYN, and LCK was not affected by hypoxia (Fig. S3A). FYN mRNA expression was not induced by hypoxia in two breast cancer cell lines (Fig. S3B). Introns 2 and 13 of the FYN gene each contained a candidate HRE (designated HRE\#1 and HRE\#2, respectively) (Fig. S3C). ChIP assays revealed that hypoxia induced significant binding of HIF$1 \alpha$, HIF- $2 \alpha$ (Fig. 3C and 3E) and HIF-1 $\beta$ (Fig. 3D and 3F) to both sites. A 55-bp sequence spanning either wild type (WT) or mutant (MUT; 5'-ACGTG-3' to 5'-AAAAG-3') HIF binding site was inserted into pGL2-promoter. Firefly luciferase activity was significantly induced by hypoxia in Hep3B cells transfected with FYN HRE\#1-WT (Fig. 3G) or FYN HRE\#2-WT (Fig. 3H), and the hypoxic induction was significantly decreased in cells transfected with HRE\#1-MUT or HRE\#2-MUT.

To confirm that FYN signals to ERK1/2, we stably knocked down FYN expression in Hep3B cells with two different shRNAs, shFYN-1 and shFYN-2 (Fig. S3D and Fig. 3I). ERK phosphorylation was induced by hypoxia in the shNT subclone, but not in the shFYN-1 or shFYN-2 subclone (Fig. 3I). In addition, hypoxia significantly increased proliferation of the shNT subclone but not the shFYN subclones (Fig. 3J). Taken together, these results indicate that FYN is a HIF-regulated intermediary that is required for the activation of ERK1/2 signaling and proliferation of Hep3B cells exposed to hypoxia.

\section{AMPA receptor antagonist inhibits Hep3B tumor xenograft growth}

Having demonstrated that activation of AMPA-type glutamate receptors stimulates FYN $\rightarrow$ ERK signaling that results in the proliferation of hypoxic Hep3B cells, we next asked whether inhibiting this pathway using the AMPA receptor antagonist GYKI 52466 would have anti-cancer effects in vivo. Hep3B cells were injected subcutaneously into the right flank of severe combined immune deficiency (SCID) mice. Administration of the AMPA receptor antagonist significantly impaired tumor growth (Fig. 4A) without affecting body weight (Fig. 4B). Immunoblot analysis revealed that tumors from GYKI 52466 treated mice had a significantly decreased ratio of phosphorylated:total ERK (Fig. 4C). Ki67 immunohistochemistry, as a measure of cancer cell proliferation in vivo, revealed a significant decrease in the number of $\mathrm{Ki}^{2} 7^{+}$cells in xenografts from mice treated with GYKI 52466 (Fig. 4D and Fig. 4E). Taken together, the data in Fig. 1-4 indicate that a signaling pathway consisting of HIFs, SLC1A1/3, GRIA2/3, FYN, and ERK1/2 contributes to cell proliferation in Hep3B cells cultured under hypoxic conditions and in Hep3B tumor xenografts (Fig. 4F).

We next analyzed the prognostic implication of the HIF regulated genes involved in glutamate signaling in hepatocellular carcinoma (SLC1A1, SLC1A3, GRIA2, GRIA3 and $F Y N$ ) using PROGgene [41] to analyze the GSE 10141 mRNA expression data set from 80 surgically resected hepatomas [42]. High expression of the gene set (greater than the median value) was significantly associated with decreased patient survival (hazard ratio $=$ $2.7, P<0.05$; Fig. S3E). 


\section{SLC1A1/3, GRIA3, and FYN expression correlate with HIF target genes in ccRCC}

Next, we investigated whether the glutamateAMPA receptor-SRC family kinase signaling axis is active in other cancer cell types. Given the key role of HIFs in this pathway, we analyzed ccRCCs because VHL loss-of-function is common and represents an $\mathrm{O}_{2}$ independent mechanism to activate HIFs in cancer cells. Analyzing gene expression data from 42 ccRCCs in the

A

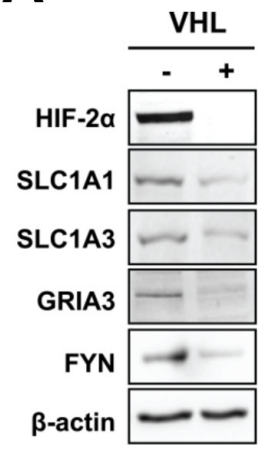

B
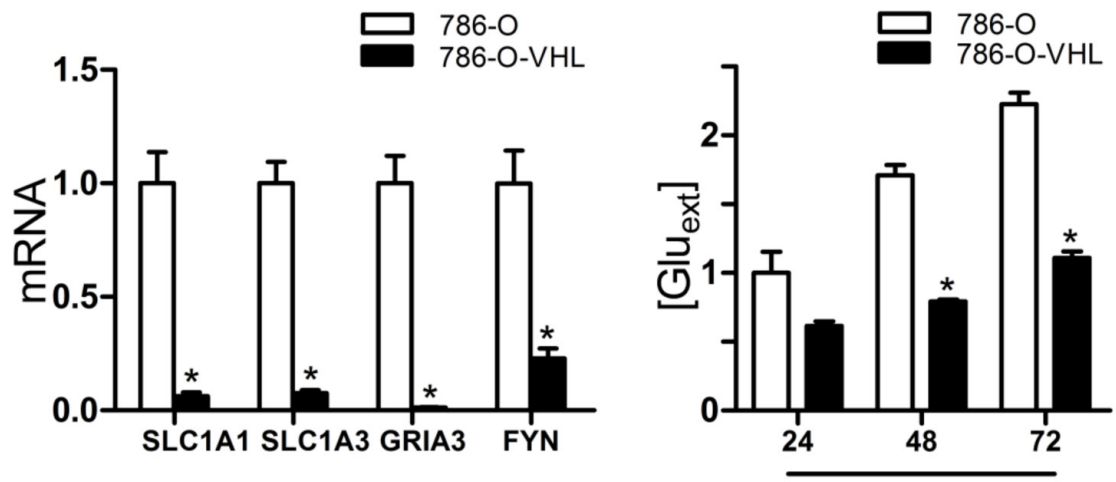

Time (h)

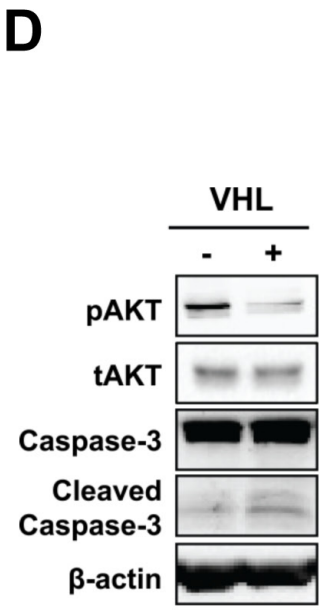

$\mathbf{E}$
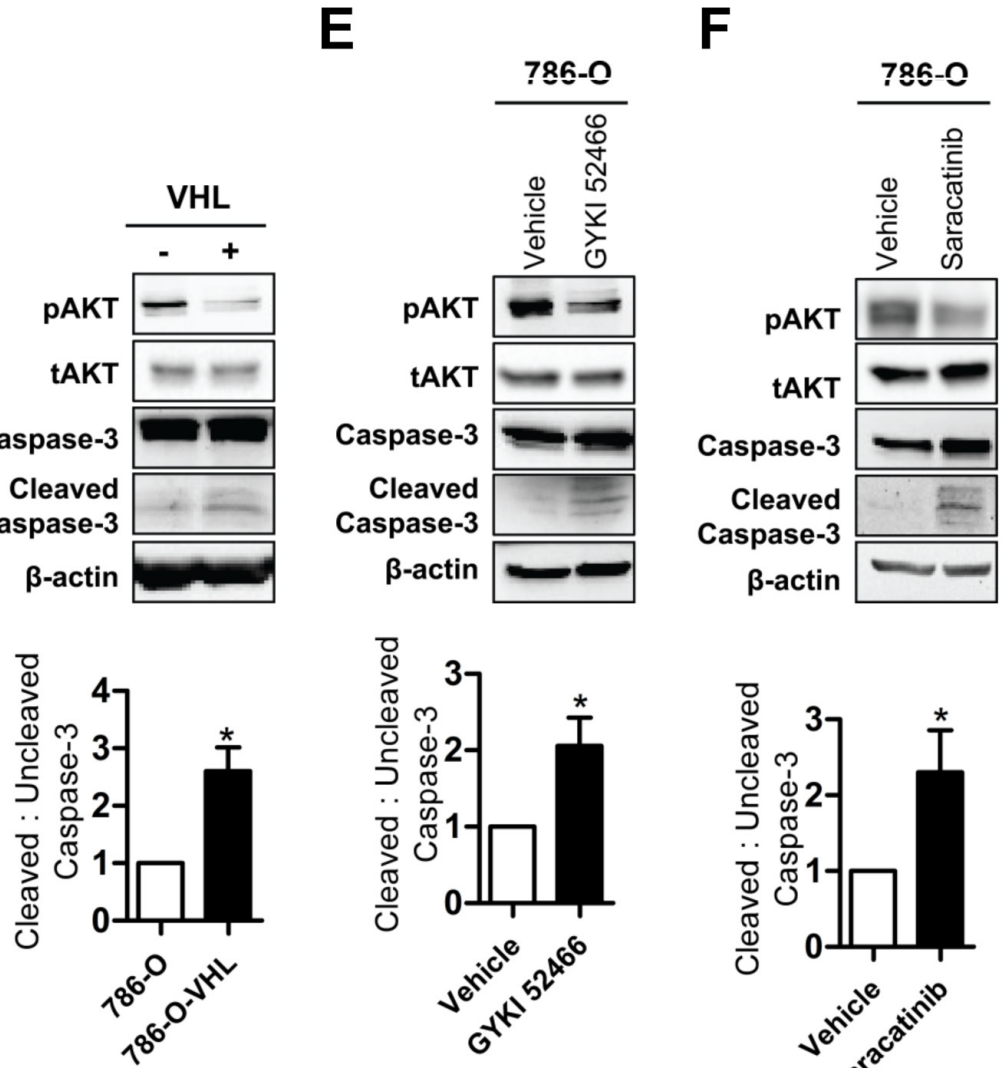

G
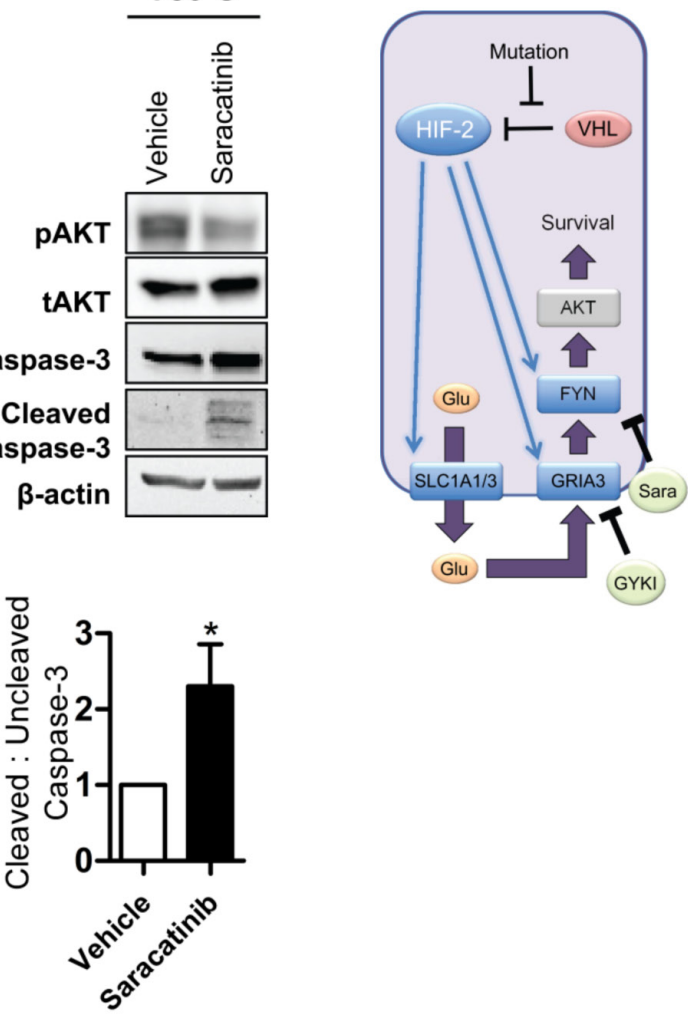

Figure 5: HIF-mediated glutamate signaling in 786-O ccRCC cells. (A-B) Immunoblot (A) and RT-qPCR (B) assays of 786-O $(-)$ and 786-O-VHL (+) cells. ${ }^{~} P<0.05$ vs 786-O. (C) Glutamate concentrations in media were measured, corrected for cell number, and normalized to results for 786-O cells cultured for $24 \mathrm{~h} .{ }^{*} P<0.05$ vs $786-\mathrm{O}$ at $48 \mathrm{~h}$ and at $72 \mathrm{~h}$, Student's $t$ test. (D) Immunoblot assays were performed to detect: phosphorylated AKT (pAKT-Ser473) and total AKT (tAKT); and full length uncleaved and cleaved Caspase-3. (E-F) 786-O cells were treated with vehicle, GYKI 52466 (E), or Saracatinib (F) for $24 \mathrm{~h}$ and cell lysates were subjected to immunoblot assays. Quantification of the ratio of the cleaved Caspase 3 relative to the full length uncleaved Caspase-3 in the experiments shown in panel D, $\mathrm{E}$ and $\mathrm{F}$ below the blots. ${ }^{*} P<0.05$, Student's $t$ test. (G) The mechanisms and consequences of HIF-mediated glutamate signaling in 786-O cells are shown. Data are mean $\pm \mathrm{SEM}$ or a representative blot from $\geq 3$ experiments. 
International Cancer Genome Consortium [43] revealed that SLC1A1, GRIA3 and FYN mRNA abundance was each significantly correlated with the expression of six known HIF target genes (Table 1). SLC1A3 mRNA abundance was significantly correlated with 3 of the 6 target genes. For comparison, expression of $P K M 2$, another HIF target gene, was also correlated with 3 of the 6 genes. RPL4 was analyzed as a representative non-HIF target gene. As expected, none of the above genes showed significant correlation with RPL4. These data suggested that genes involved in glutamate receptor signaling might be regulated by HIFs in ccRCC.

\section{HIF-dependent glutamate signaling stimulates survival of 786-O cells}

Because one-third of ccRCC tumors with VHL lossof-function exclusively overexpress HIF-2 $\alpha$ ("H2") and two-thirds overexpress both HIF-1 $\alpha$ and HIF-2 $\alpha$ ("H1H2") [44], we analyzed two VHL mutant ccRCC cell lines, 786$\mathrm{O}$ and $\mathrm{RCC} 4$, which represent the $\mathrm{H} 2$ and $\mathrm{H} 1 \mathrm{H} 2$ subtypes, respectively. Only HIF-2 $\alpha$ was constitutively expressed in 786-O cells and, after reintroduction of wild-type VHL, HIF-2 $\alpha$ expression was markedly decreased under nonhypoxic conditions (Fig. 5A). A decrease in SLC1A1, SLC1A3, GRIA3 and FYN protein and mRNA abundance was observed in the 786-O-VHL subclone (Fig. 5A-B). Extracellular glutamate accumulated in a time-dependent manner in the media of 786-O and 786-O-VHL cells. However, conditioned medium from 786-O cells contained significantly more glutamate than 786-O-VHL at every time point (Fig. 5C). We examined the effects of Evans Blue, an inhibitor of vesicular glutamate transporters, and Sulfasalazine, an inhibitor of the cystine-glutamate antiporter [45], on extracellular glutamate concentrations. Neither inhibitor affected cell proliferation (Fig. S4A) or extracellular glutamate concentrations (Fig. S4B). These results suggest that glutamate efflux in 786-O cells is mediated by the membrane glutamate transporters SLC1A1 and SLC1A3.

In contrast to the effect of HIF activation in Hep3B cells, 786-O cells did not have any growth advantage over 786-O-VHL cells (Fig. S4A). However, 786-O cells exhibited decreased apoptosis compared to 786-O-VHL cells, as measured by Annexin V staining and flow cytometry (Fig. S5). The PI3K/AKT pathway is a major anti-apoptotic signaling pathway and AKT phosphorylation (at Ser-473) was increased, and cleaved (activated) caspase 3 was decreased, in 786-O as compared to 786-O-VHL cells (Fig. 5D). To determine whether glutamate-glutamate receptor-SRC family kinase signaling was involved, we treated 786-O cells with either the AMPA receptor antagonist GYKI 52466 or the SRC family kinase inhibitor Saracatinib. Both inhibitors decreased the phosphorylation of AKT and increased caspase- 3 cleavage
(Fig. 5E and 5F). Taken together, these data indicate that in 786-O ccRCC cells, HIF-2 $\rightarrow$ SLC1A1/3 $\rightarrow$ GRIA3 $\rightarrow$ FYN $\rightarrow$ AKT signaling stimulates cell survival by inhibiting apoptosis.

\section{HIF-dependent glutamate signaling stimulates RCC4 migration and invasion}

To further confirm the involvement of glutamate signaling in ccRCC cells, we analyzed RCC4 cells, which are VHL-null cells that constitutively express both HIF$1 \alpha$ and HIF- $2 \alpha$ protein under non-hypoxic conditions. Stable transfection of an expression vector encoding wildtype VHL abolished the increased abundance of HIF-1 $\alpha$ and HIF-2 $\alpha$ protein under non-hypoxic conditions (Fig. 6A). Similarly, the abundance of glutamate transporters SLC1A1 and SLC1A3 was decreased at the protein (Fig. 6A) and mRNA (Fig. 6B) levels in the RCC4-VHL subclone. RCC4 cells responded differently than 786-O cells to re-expression of wild type VHL. First, GRIA2 protein levels were reduced; and second, the abundance of FYN was not affected, but the phosphorylation of LYN, another SRC family kinase member, was decreased in RCC4-VHL cells (Fig. 6A-B). However, as in the case of 786-O, VHL-null RCC4 cells released significantly more glutamate than the RCC4-VHL subclone (Fig. 6C). In addition, when RCC4-VHL cells were exposed to hypoxia, these cells released more glutamate (Fig. S6).

We next analyzed RCC4 subclones that stably expressed an empty vector (shEV) or vector encoding HIF$1 \alpha(\operatorname{sh} 1 \alpha)$ or HIF- $2 \alpha(\operatorname{sh} 2 \alpha)$ shRNA, or vectors encoding both HIF- $1 \alpha$ and HIF- $2 \alpha$ shRNAs $(\operatorname{sh} 1 \alpha / 2 \alpha)$ to determine whether HIF- $1 \alpha$ or HIF- $2 \alpha$ was specifically required for SLC1A1 and SLC1A3 expression in RCC4 cells. SLC1A1 and SLC1A3 mRNA (Fig. 6D-E) and protein (Fig. 6F) overexpression were abrogated when HIF-1 $\alpha$, HIF-2 $\alpha$, or both were knocked down in RCC4 cells.

In contrast to the increased proliferation of Hep3B cells under hypoxia and the decreased apoptosis of VHLnull 786-O cells, we found that VHL-null RCC4 cells exhibited increased migration and invasion as compared to RCC4-VHL cells (Fig. 6G-H, left panel). The glutamate receptor antagonist GYKI 52466 significantly impaired migration and invasion in RCC4 cells but not RCC4VHL cells (Fig. 6G-H, left panel). In contrast, Saracatinib decreased migration and invasion in both RCC4 and RCC4-VHL cells (Fig. 6G-H, right panel), demonstrating that SRC family kinase activity is required for basal as well as HIF-dependent migration and invasion. Taken together, the data indicate that HIF-1/2 $\rightarrow$ SLC1A1/3 $\rightarrow$ GRIA2 $\rightarrow$ LYN signaling stimulates migration and invasion of VHL-null RCC4 cells (Fig. 6I). 
A

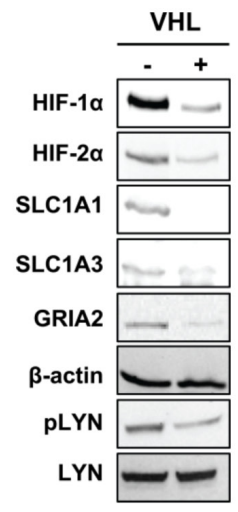

F

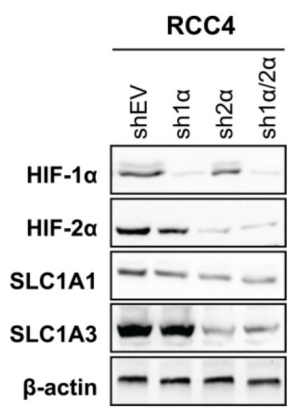

H

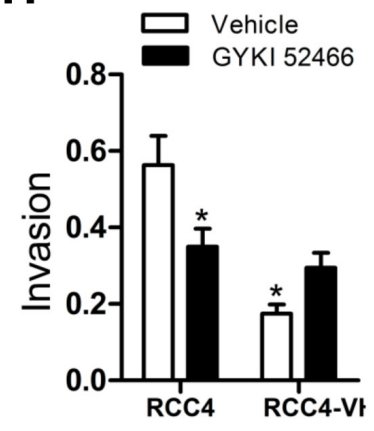

B

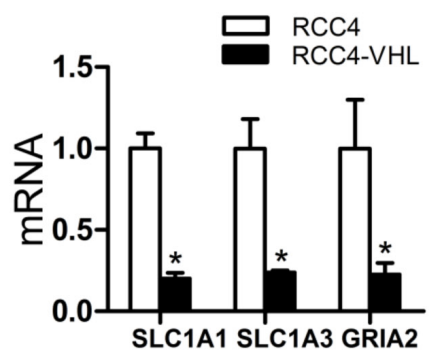

D

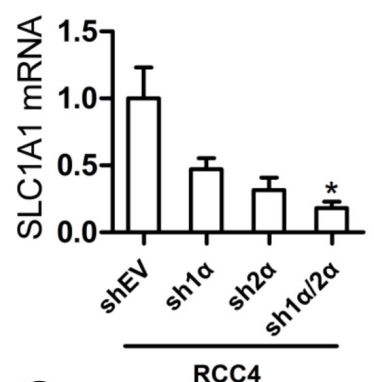

G

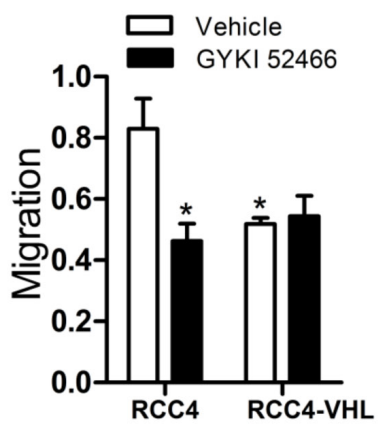

C

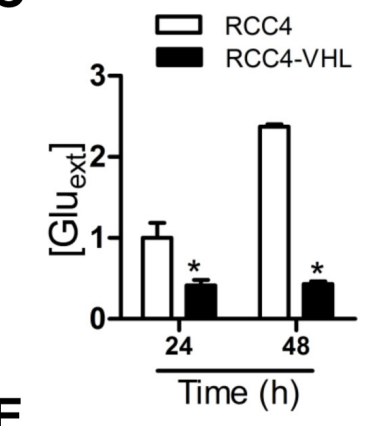

E
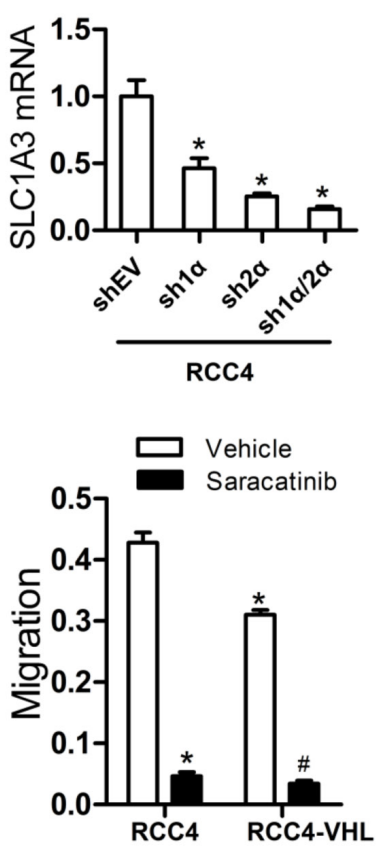

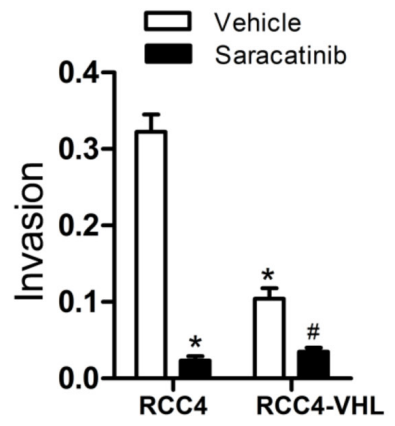

Figure 6: HIF-mediated glutamate signaling in RCC4 cells. (A-B) Immunoblot (A) and RT-qPCR (B) assays of RCC4 (-) and RCC4-VHL ( + ) cells were performed. " $P<0.05$ vs RCC4, Student's $t$ test. (C) Glutamate concentrations were measured in conditioned media, and normalized to RCC4 at $24 \mathrm{~h} .{ }^{*} P<0.05$ vs RCC4 at $24 \mathrm{~h}$ and at $48 \mathrm{~h}$, Student's $t$ test. (D-F) RT-qPCR (D, E) and immunoblot (F) assays were performed with RCC4 subclones. ${ }^{*} P<0.05$ vs shEV, ANOVA with Bonferroni post-test. (G) Cells were seeded in a Boyden chamber in the presence of vehicle, GYKI 52466 (left panel), or Saracatinib (right panel) and migration through uncoated inserts in response to FBS was determined by crystal violet staining. ${ }^{*} P<0.05$ vs RCC4-vehicle, ${ }^{\#} P<0.05$ vs RCC4-VHL-vehicle. (H) Cells were seeded on Matrigel-coated inserts in the presence of vehicle, GYKI 52466 (left panel), or $10 \mu \mathrm{M}$ Saracatinib (right panel). Cells that invaded through the coated inserts were determined by crystal violet staining. ${ }^{*} P<0.05$ vs RCC4-vehicle; ${ }^{\#} P<0.05$ vs RCC4-VHLvehicle. (I) The mechanisms and consequences of HIF-mediated glutamate signaling in RCC4 cells are shown. Data are mean \pm SEM or a representative blot from $\geq 3$ experiments. 


\section{DISCUSSION}

The results presented here delineate molecular mechanisms by which HIFs mediate enhanced glutamate receptor signaling in Hep3B, 786-O, and $\mathrm{RCC} 4$ cancer cells through the direct, coordinate transcriptional activation of multiple genes encoding glutamate transporters and glutamate receptors in response to HIF activity resulting either from hypoxia or VHL loss-offunction. In Hep3B and 786-O cells, HIFs also activated transcription of the $F Y N$ gene, which served to amplify signaling downstream of the glutamate receptors. Despite the similar HIF-mediated transcriptional responses and activation of SRC family kinases, the ultimate biological consequences of glutamate signaling were different: in Hep3B cells, FYN signaled to ERK1/2 to stimulate cell proliferation; in 786-O cells, FYN signaled to AKT to stimulate cell survival; and in RCC4 cells, LYN signaling stimulated cell migration and invasion.

\section{Hypoxia induces cancer cell glutamate efflux mediated by SLC1A1 and SLC1A3}

Prior studies demonstrated that cancer cells release glutamate, but our data demonstrate that increased glutamate efflux occurs in hepatocellular carcinoma cells in response to hypoxic conditions and in ccRCC cells due to VHL loss-of-function. In both cases, augmented glutamate efflux results from HIF-dependent SLC1A1 and SLC1A3 expression. The membrane glutamate transporters encoded by these genes conventionally mediate glutamate transport into cells under physiological conditions, but glutamate transport is reversible, with glutamate efflux occurring in ischemic tissue [46]. Over $50 \%$ of glutamate release by glioma cell lines was attributed to the $\mathrm{x}_{\mathrm{c}}^{-}$cystine/glutamate antiporter, which has been implicated in other cancer cells that release glutamate $[45,47]$. However, the reported increase of glutamate and decrease of cystine in the media was not equimolar, with 2- to 7-fold more glutamate secreted [48], which suggests that even under non-hypoxic conditions additional mechanisms must contribute to glutamate release in those cancer cells. SLC1A2, another major membrane glutamate transporter in the CNS, mediates up to $95 \%$ of glutamate uptake in the brain and is frequently silenced in gliomas due to DNA methylation [49, 50]. Neither SLC7A11 nor SLC1A2 mRNA levels were affected by HIF activation in Hep3B cells or ccRCC cells, and inhibitors of the cystine/ glutamate antiporter or vesicular glutamate transporter activity had no effect on extracellular glutamate concentration in 786-O cells, excluding their contribution to HIF-mediated glutamate release in these cells.

\section{Functional consequences of glutamate receptor signaling vary among cancer cell lines}

Several prior studies reported functional effects of AMPA receptors in cancer. GRIA1 and GRIA3 were shown to promote tumor progression in glioma $[20,51]$ and pancreatic cancer [52]. In contrast, GRIA4 is subject to DNA methylation $[53,54]$ and inhibition of GRIA4 expression increased cancer cell proliferation [22]. In the case of GRIA2, there are conflicting reports regarding its role in cancer biology. GRIA2 expression is upregulated in uterine leiomyoma and gastrointestinal neuroendocrine carcinoma compared to adjacent normal tissues [5557]. In contrast, GRIA2 expression is lost in high-grade glioma and forced expression in glioma cells inhibited proliferation and induced apoptosis [58]. In pancreatic ductal adenocarcinoma, AMPA receptor signaling to KRAS and MAPK promoted migration and invasion [59]. However, the molecular basis for AMPA receptor expression was not determined. In the current study, we demonstrate that HIF-dependent GRIA2 and GRIA3 expression in hepatocellular carcinoma and ccRCC cell lines promotes tumor progression through effects on proliferation, survival, migration and invasion. Analysis of gene expression data from human ccRCC biopsies indicates that the same transcriptional circuits are active in vivo, thereby establishing the clinical relevance of our findings.

We have shown that hypoxia is a microenvironmental stimulus that triggers HIF-dependent expression of membrane glutamate transporters as well as AMPA-type glutamate receptors in hepatocellular carcinoma cells. In a mouse model of pancreatic neuroendocrine tumor and in selected human cancers including breast cancer, increased interstitial fluid pressure was reported to stimulate increased expression of vesicular glutamate transporters, activation of NMDAtype glutamate receptors and downstream MEK-MAPK and $\mathrm{CaM}$ kinase signaling, leading to proliferation and invasion [60]. Taken together, these results suggest that glutamate signaling is common among human cancers whereas the activating mechanisms are different.

\section{Therapeutic implications}

Our results demonstrate that HIF-mediated glutamate efflux and signaling via AMPA-type glutamate receptors promote multiple aspects of cancer progression and that administration of an AMPA receptor antagonist significantly inhibits Hep3B tumor xenograft growth. The AMPA receptor antagonist talampanel was well tolerated but had no activity as a single agent in a Phase II clinical trial involving patients with recurrent glioma [61]. Previous studies have demonstrated that administration of HIF inhibitors blocks the growth of Hep3B [62] and 
ccRCC [63] tumor xenografts. In addition to blocking glutamate receptor signaling, HIF inhibitors block many other pathways that are critical for cancer progression $[7-9,64,65]$. Further studies are needed to evaluate the potential benefit of HIF inhibitors in the treatment of advanced liver and kidney cancers, which respond poorly to current chemotherapy regimens.

\section{METHODS}

\section{Cell culture and reagents}

Hep3B, 786-O, RCC4, MDA-MB-231, MDAMB-435 and HEK293T cells were cultured in Dulbecco's Modified Eagle's Medium (DMEM) supplemented with $10 \%$ heat-inactivated fetal bovine serum, 100 units $/ \mathrm{mL}$ of penicillin, and $100 \mu \mathrm{g} / \mathrm{mL}$ of streptomycin. G418 $(0.8 \mathrm{mg} /$ $\mathrm{mL}$ ) was added to the medium of 786-O-VHL and RCC4VHL cells. Culture conditions for RCC4-shEV, RCC4$\operatorname{sh} 1 \alpha$, RCC4-sh $2 \alpha$, and RCC4-sh $1 \alpha / 2 \alpha$ were as described [66]. Cells were maintained at $37^{\circ} \mathrm{C}$ in a $5 \% \mathrm{CO}_{2} / 95 \%$ air incubator. For hypoxic exposure, cells were placed in a modular incubator chamber (Billups-Rothenberg) flushed with $1 \% \mathrm{O}_{2} / 5 \% \mathrm{CO}_{2} /$ balance $\mathrm{N}_{2}$ and incubated at $37^{\circ} \mathrm{C}$. GYKI 52466, MK-801, Evans Blue and Sulfasalazine were purchased from Sigma-Aldrich. U0126 was from LC laboratories. Saracatinib was purchased from Selleckchem.

\section{Plasmid constructs}

The indicated 55-bp oligonucleotides were inserted into pGL2-Promoter (Promega). All plasmid constructs were confirmed by nucleotide sequencing.

\section{shRNA and lentivirus production}

Recombinant lentivirus was generated by transfection of HEK293T cells with the transducing vector pLKO.1-puro encoding shRNA, together with packaging vectors pMD.G and pCMV-dR8.91, using PolyJet (SignaGen). After $48 \mathrm{~h}$, medium containing viral particles was harvested and passed through a 0.45 $\mu \mathrm{m}$ filter (Millipore). Hep3B cells were transduced with viral supernatant in the presence of $8 \mu \mathrm{g} / \mathrm{mL}$ of Polybrene (Sigma-Aldrich). After $24 \mathrm{~h}$, cells were replenished with fresh medium containing $2 \mu \mathrm{g} / \mathrm{mL}$ of puromycin. Cells were maintained in puromycin-containing medium for selection of stable transfectants. shRNA sequences are listed in Table S1.

\section{Glutamate measurement}

Glutamate concentrations in media were measured using a colorimetric glutamate assay (BioVision) in which optical density at $\lambda=450 \mathrm{~nm}$ was determined using a microplate reader (PerkinElmer) and glutamate concentration was interpolated from a standard curve and corrected for differences in cell number.

\section{RT and qPCR}

RNA was extracted using TRIzol (Invitrogen), precipitated with isopropanol, treated with DNase I (Ambion), and reverse transcribed with the iScript cDNA Synthesis kit (Bio-Rad). qPCR analysis was performed using Maxima SYBR Green Master Mix (Fermentas) with the iCycler Real-time PCR Detection System (BioRad). The $2^{-\Delta \Delta \mathrm{Ct}}$ method was used to calculate relative gene expression. Results were normalized to the $18 \mathrm{~S}$ rRNA signal. Primer sequences are listed in Table S1.

\section{Immunoblot assays}

Whole cell lysates were prepared in modified RIPA buffer and proteins were fractionated by SDSPAGE. The following primary antibodies were used: HIF-1 $\alpha$ (BD Biosciences); HIF-2 $\alpha$, SLC1A1, SLC1A3, GRIA2, GRIA3, FYN, pLYN (Tyr396), LYN, SRC, LCK, ERK, Caspase-3, and AKT (Novus Biologicals); and phosphorylated ERK, phosphorylated AKT (Ser473), and $\beta$-actin (Santa Cruz). HRP-conjugated secondary rabbit antibody was purchased from GE Healthcare Life Sciences; all other secondary antibodies were obtained from Santa Cruz.

\section{ChIP assays}

Hep3B cells were cross-linked with $1 \%$ formaldehyde for $10 \mathrm{~min}$ and quenched in 0.125 $\mathrm{M}$ glycine. Cells were sonicated using a Bioruptor (Diagenode). Sonicated lysates were precleared with salmon sperm DNA/protein A agarose slurry (Millipore). IgG (Santa Cruz and Novus Biologicals) or primary antibody against HIF-1 $\alpha$ (Santa Cruz), HIF-2 $\alpha$ (Novus Biologicals), or HIF-1 $\beta$ (Novus Biologicals) was incubated with precleared lysates. Salmon sperm DNA/ protein A agarose slurry was added and the agarose beads were washed sequentially with: low- and high-salt immune complex wash buffers; LiCl immune complex wash buffer; and twice with TE buffer. DNA was eluted in $1 \% \mathrm{SDS} / 0.1 \mathrm{M} \mathrm{NaHCO}_{3}$ and crosslinks were reversed by addition of $\mathrm{NaCl}$ to $0.2 \mathrm{M}$. Proteinase $\mathrm{K}$ was added to degrade any protein including nucleases. DNA was recovered by phenol-chloroform extraction and ethanol 
precipitation, treated with RNase, and analyzed by qPCR. Primer sequences are listed in Table S1.

\section{Luciferase reporter assays}

Hep3B cells in 48-well plates were co-transfected with pGL2 firefly luciferase reporter plasmid with HREWT or HRE-MUT sequences and pSV-Renilla. $24 \mathrm{~h}$ after transfection, cells were exposed to $20 \%$ or $1 \% \mathrm{O}_{2}$ for 24 $\mathrm{h}$ and lysed. Luciferase activities were determined with a multi-well luminescence reader (PerkinElmer) using the Dual-Luciferase Reporter Assay System (Promega). Firefly:Renilla luciferase ratio was calculated and normalized to HRE-WT- $20 \% \mathrm{O}_{2}$.

\section{Xenograft assays}

All animal protocols were approved by The Johns Hopkins University Animal Care and Use Committee. Male SCID mice 5 to 7 weeks of age were used. Hep3B cells were resuspended at $2.5 \times 10^{7}$ cells $/ \mathrm{ml}$ in a $1: 1 \mathrm{mix}$ of DMEM:Matrigel (BD Biosciences). A $200-\mu \mathrm{L}$ suspension containing $5 \times 10^{6}$ cells was implanted subcutaneously into the right flank. Mice were monitored for body weight and tumor volume $\left(\mathrm{mm}^{3}\right)$, which was calculated as length $(\mathrm{mm}) \times$ [width $(\mathrm{mm})]^{2} \times 0.52$. When tumor volume reached $200 \mathrm{~mm}^{3}$ on day 45 , mice were randomly divided into control and treatment groups and received daily intraperitoneal injections of vehicle or $5 \mathrm{mg} / \mathrm{kg}$ of GYKI 52466, respectively.

\section{Immunohistochemistry}

Xenograft tumors were fixed in $10 \%$ formalin, paraffin embedded, and 5- $\mu \mathrm{m}$ sections were prepared, dewaxed with xylene, hydrated with graded ethanol, followed by antigen retrieval using citrate buffer ( $\mathrm{pH}$ 6.1). The LSAB + System HRP kit (DAKO) was used with Ki67 antibody (1:200, Novus Biologicals). Sections were counterstained with Mayer's hematoxylin, dehydrated through graded ethanol into xylene, and mounted. The Ki67 staining was quantified using ImageJ software (NIH) [64].

\section{Flow cytometry}

Cultured cells were washed, detached, and incubated with PE-conjugated Annexin V and 7-amino-actinomycin (7-AAD) in $1 \mathrm{X}$ binding buffer (BD Pharmingen) for $15 \mathrm{~min}$ at room temperature in the dark. Cell samples were analyzed with a LSR-II flow cytometer (Becton Dickinson).

\section{Migration and invasion assays}

For migration assays, RCC4 and RCC4-VHL cells were seeded onto uncoated inserts of a 24-well Transwell chamber (8-mm pore size; Costar) and allowed to migrate for $16 \mathrm{~h}$ in the presence of vehicle, $250 \mu \mathrm{M}$ GYKI 52466, or $10 \mu \mathrm{M}$ Saracatinib. For invasion assays, Transwell inserts were coated with Matrigel (BD Biosciences) at $37^{\circ} \mathrm{C}$ for $4 \mathrm{~h}$ and then cells were seeded onto the inserts. Cells were incubated for $24 \mathrm{~h}$ in the presence of vehicle, $250 \mu \mathrm{M}$ GYKI 52466, or $10 \mu \mathrm{M}$ Saracatinib. The cells that remained on the upper surface of the filter were removed with a cotton swab. The cells that migrated/invaded to the underside of the inserts were fixed with $100 \%$ methanol for $5 \mathrm{~min}$ and stained with $0.1 \%$ crystal violet for $20 \mathrm{~min}$. Membranes were cut from the Transwell and rinsed in 1 $\mathrm{mL}$ of $33 \%$ acetic acid. Absorbance was read at $570 \mathrm{~nm}$.

\section{Correlation analysis of microarray expression data}

Gene expression data from Kidney Renal Clear Cell Carcinoma (TCGA) were obtained from the International Cancer Genome Consortium (http://icgc.org/). Pearson's correlation coefficient was used to determine $p$ values for co-expression.

\section{Statistical analysis}

Data were analyzed with an unpaired two-tailed Student's $t$-test or ANOVA followed by Bonferroni posttest as indicated in the figure legend. A $p$ value $<0.05$ was considered significant.

\section{ACKNOWLEDGMENTS}

We thank Gerald Hart, Chi Dang, Akhilesh Pandey and Barbara Slusher for helpful advice and discussions. We are grateful to Karen Padgett (Novus Biologicals) for providing IgG and antibodies against HIF- $2 \alpha$, HIF- $1 \beta$, SLC1A1, SLC1A3, GRIA2, GRIA3, FYN, pLYNY396, LYN, SRC, LCK, ERK, Caspase-3, AKT, and Ki67. Cancer research in the Semenza lab is funded by grants from the American Cancer Society, Department of Defense, and National Cancer Institute. D.M.G and W.L. were supported by NIH Grants K99-CA181352 and K99-CA168746, respectively. G.L.S. is the C. Michael Armstrong Professor at the Johns Hopkins University School of Medicine and an American Cancer Society Research Professor. The authors declare that they have no competing interests. 


\section{REFERENCES}

1. Wang GL, Jiang BH, Rue EA and Semenza GL. Hypoxiainducible factor 1 is a basic-helix-loop-helix-PAS heterodimer regulated by cellular $\mathrm{O} 2$ tension. Proc Natl Acad Sci U S A. 1995; 92(12):5510-5514.

2. Keith B, Johnson RS and Simon MC. HIF- $1 \alpha$ and HIF-2 $\alpha$ : sibling rivalry in hypoxic tumor growth and progression. Nat Rev Cancer. 2012; 12(1):9-22.

3. Prabhakar NR and Semenza GL. Adaptive and maladaptive cardiorespiratory responses to continuous and intermittent hypoxia mediated by hypoxia-inducible factors 1 and 2 . Physiol Rev. 2012; 92(3):967-1003.

4. Kaelin WG, Jr. and Ratcliffe PJ. Oxygen sensing by metazoans: the central role of the HIF hydroxylase pathway. Mol Cell. 2008; 30(4):393-402.

5. Semenza GL. Hypoxia-inducible factors in physiology and medicine. Cell. 2012; 148(3):399-408.

6. Dunwoodie SL. The role of hypoxia in development of the Mammalian embryo. Dev Cell. 2009; 17(6):755-773.

7. Semenza GL. Defining the role of hypoxia-inducible factor 1 in cancer biology and therapeutics. Oncogene. 2010; 29(5):625-634.

8. Harris AL. Hypoxia--a key regulatory factor in tumour growth. Nat Rev Cancer. 2002; 2(1):38-47.

9. Semenza GL. Targeting HIF-1 for cancer therapy. Nat Rev Cancer. 2003; 3(10):721-732.

10. Cancer Genome Atlas Research Network. Comprehensive molecular characterization of clear cell renal cell carcinoma. Nature. 2013; 499(7456):43-49.

11. Nedergaard M, Takano T and Hansen AJ. Beyond the role of glutamate as a neurotransmitter. Nat Rev Neurosci. 2002; 3(9):748-755.

12. Ye ZC and Sontheimer H. Glioma cells release excitotoxic concentrations of glutamate. Cancer Res. 1999; 59(17):4383-4391.

13. Takano $\mathrm{T}$, Lin JH, Arcuino G, Gao Q, Yang $\mathrm{J}$ and Nedergaard M. Glutamate release promotes growth of malignant gliomas. Nat Med. 2001; 7(9):1010-1015.

14. Rzeski W, Turski L and Ikonomidou C. Glutamate antagonists limit tumor growth. Proc Natl Acad Sci U S A. 2001; 98(11):6372-6377.

15. Meldrum BS. Glutamate as a neurotransmitter in the brain: review of physiology and pathology. J Nutr. 2000; 130(4S Suppl):1007S-1015S.

16. Pollock PM, Cohen-Solal K, Sood R, Namkoong J, Martino JJ, Koganti A, Zhu H, Robbins C, Makalowska I, Shin SS, Marin Y, Roberts KG, Yudt LM, Chen A, Cheng J, Incao A, Pinkett HW, Graham CL, Dunn K, Crespo-Carbone SM, Mackason KR, Ryan KB, Sinsimer D, Goydos J, Reuhl KR, Eckhaus M, Meltzer PS, Pavan WJ, Trent JM and Chen S. Melanoma mouse model implicates metabotropic glutamate signaling in melanocytic neoplasia. Nat Genet. 2003; 34(1):108-112.
17. Choi KY, Chang K, Pickel JM, Badger JD 2nd and Roche $\mathrm{KW}$. Expression of the metabotropic glutamate receptor 5 (mGluR5) induces melanoma in transgenic mice. Proc Natl Acad Sci U S A. 2011; 108(37):15219-15224.

18. Stepulak A, Luksch H, Gebhardt C, Uckermann O, Marzahn J, Sifringer M, Rzeski W, Staufner C, Brocke KS, Turski $\mathrm{L}$ and Ikonomidou C. Expression of glutamate receptor subunits in human cancers. Histochem Cell Biol. 2009; 132(4):435-445.

19. Namkoong J, Shin SS, Lee HJ, Marin YE, Wall BA, Goydos JS and Chen S. Metabotropic glutamate receptor 1 and glutamate signaling in human melanoma. Cancer Res. 2007; 67(5):2298-2305.

20. de Groot JF, Piao Y, Lu L, Fuller GN and Yung WK. Knockdown of GluR1 expression by RNA interference inhibits glioma proliferation. J Neurooncol. 2008; 88(2):121-133.

21. Watanabe K, Kanno T, Oshima T, Miwa H, Tashiro C and Nishizaki T. The NMDA receptor NR2A subunit regulates proliferation of MKN45 human gastric cancer cells. Biochem Biophys Res Commun. 2008; 367(2):487-490.

22. Luksch H, Uckermann O, Stepulak A, Hendruschk S, Marzahn J, Bastian S, Staufner C, Temme A and Ikonomidou C. Silencing of selected glutamate receptor subunits modulates cancer growth. Anticancer Res. 2011; 31(10):3181-3192.

23. Kan Z, Jaiswal BS, Stinson J, Janakiraman V, Bhatt D, Stern HM, Yue P, Haverty PM, Bourgon R, Zheng J, Moorhead M, Chaudhuri S, Tomsho LP, Peters BA, Pujara K, Cordes S, Davis DP, Carlton VE, Yuan W, Li L, Wang W, Eigenbrot C, Kaminker JS, Eberhard DA, Waring P, Schuster SC, Modrusan Z, Zhang Z, Stokoe D, de Sauvage FJ, Faham M and Seshagiri S. Diverse somatic mutation patterns and pathway alterations in human cancers. Nature. 2010; 466(7308):869-873.

24. Prickett TD, Wei X, Cardenas-Navia I, Teer JK, Lin JC, Walia V, Gartner J, Jiang J, Cherukuri PF, Molinolo A, Davies MA, Gershenwald JE, Stemke-Hale K, Rosenberg SA, Margulies EH and Samuels Y. Exon capture analysis of G protein-coupled receptors identifies activating mutations in GRM3 in melanoma. Nat Genet. 2011; 43(11):11191126.

25. Savage SA, Mirabello L, Wang Z, Gastier-Foster JM, Gorlick R, Khanna C, Flanagan AM, Tirabosco R, Andrulis IL, Wunder JS, Gokgoz N, Patino-Garcia A, Sierrasesumaga L, Lecanda F, Kurucu N, Ilhan IE, Sari N, Serra M, Hattinger C, Picci P, Spector LG, Barkauskas DA, Marina N, de Toledo SR, Petrilli AS, Amary MF, Halai D, Thomas DM, Douglass C, Meltzer PS, Jacobs K, Chung CC, Berndt SI, Purdue MP, Caporaso NE, Tucker M, Rothman N, Landi MT, Silverman DT, Kraft P, Hunter DJ, Malats N, Kogevinas M, Wacholder S, Troisi R, Helman L, Fraumeni JF Jr, Yeager M, Hoover RN and Chanock SJ. Genome-wide association study identifies two susceptibility loci for osteosarcoma. Nat Genet. 2013; 45(7):799-803. 
26. Wei X, Walia V, Lin JC, Teer JK, Prickett TD, Gartner J, Davis S, Stemke-Hale K, Davies MA, Gershenwald JE, Robinson W, Robinson S, Rosenberg SA and Samuels Y. Exome sequencing identifies GRIN2A as frequently mutated in melanoma. Nat Genet. 2011; 43(5):442-446.

27. Morrison CD, Liu P, Woloszynska-Read A, Zhang J, Luo W, Qin M, Bshara W, Conroy JM, Sabatini L, Vedell P, Xiong D, Liu S, Wang J, Shen H, Li Y, Omilian AR, Hill A, Head K, Guru K, Kunnev D, Leach R, Eng KH, Darlak C, Hoeflich C, Veeranki S, Glenn S, You M, Pruitt SC, Johnson CS and Trump DL. Whole-genome sequencing identifies genomic heterogeneity at a nucleotide and chromosomal level in bladder cancer. Proc Natl Acad Sci U S A. 2014;111:E672-E681.

28. Sinclair PB, Sorour A, Martineau M, Harrison CJ, Mitchell WA, O'Neill E and Foroni L. A fluorescence in situ hybridization map of $6 q$ deletions in acute lymphocytic leukemia: identification and analysis of a candidate tumor suppressor gene. Cancer Res. 2004; 64(12):4089-4098.

29. Ibragimova I, Slifker MJ, Maradeo ME, Banumathy G, Dulaimi E, Uzzo RG and Cairns P. Genome-wide promoter methylome of small renal masses. PLoS One. 2013; 8(10):e77309.

30. Wu CS, Lu YJ, Li HP, Hsueh C, Lu CY, Leu YW, Liu $\mathrm{HP}$, Lin KH, Hui-Ming Huang T and Chang YS. Glutamate receptor, ionotropic, kainate 2 silencing by DNA hypermethylation possesses tumor suppressor function in gastric cancer. Int J Cancer. 2010; 126(11):2542-2552.

31. Kim MS, Chang X, Nagpal JK, Yamashita K, Baek JH, Dasgupta S, Wu G, Osada M, Woo JH, Westra WH, Trink B, Ratovitski EA, Moon C and Sidransky D. The N-methyl$\mathrm{D}$-aspartate receptor type $2 \mathrm{~A}$ is frequently methylated in human colorectal carcinoma and suppresses cell growth. Oncogene. 2008; 27(14):2045-2054.

32. Kim MS, Yamashita K, Chae YK, Tokumaru Y, Chang X, Zahurak M, Osada M, Park HL, Chuang A, Califano JA and Sidransky D. A promoter methylation pattern in the N-methyl-D-aspartate receptor 2B gene predicts poor prognosis in esophageal squamous cell carcinoma. Clin Cancer Res. 2007; 13(22 Pt 1):6658-6665.

33. Liu JW, Kim MS, Nagpal J, Yamashita K, Poeta L, Chang X, Lee J, Park HL, Jeronimo C, Westra WH, Mori M, Moon C, Trink B and Sidransky D. Quantitative hypermethylation of NMDAR2B in human gastric cancer. Int J Cancer. 2007; 121(9):1994-2000.

34. Tamura H, Suzuki M, Moriya Y, Hoshino H, Okamoto $\mathrm{T}$, Yoshida $\mathrm{S}$ and Yoshino I. Aberrant methylation of $\mathrm{N}$-methyl-D-aspartate receptor type 2B (NMDAR2B) in non-small cell carcinoma. BMC cancer. 2011; 11:220.

35. Seidlitz EP, Sharma MK, Saikali Z, Ghert M and Singh G. Cancer cell lines release glutamate into the extracellular environment. Clin Exp Metastasis. 2009; 26(7):781-787.

36. Nishizawa Y. Glutamate release and neuronal damage in ischemia. Life Sci. 2001; 69(4):369-381.
37. Yamaguchi F, Hirata Y, Akram H, Kamitori K, Dong Y, Sui L and Tokuda M. FOXO/TXNIP pathway is involved in the suppression of hepatocellular carcinoma growth by glutamate antagonist MK-801. BMC Cancer. 2013; 13:468.

38. Traynelis SF, Wollmuth LP, McBain CJ, Menniti FS, Vance KM, Ogden KK, Hansen KB, Yuan H, Myers SJ and Dingledine R. Glutamate receptor ion channels: structure, regulation, and function. Pharmacol Rev. 2010; 62(3):405496.

39. Hayashi $T$, Umemori $H$, Mishina $M$ and Yamamoto $T$. The AMPA receptor interacts with and signals through the protein tyrosine kinase Lyn. Nature. 1999; 397(6714):7276.

40. Razorenova OV, Finger EC, Colavitti R, Chernikova SB, Boiko AD, Chan CK, Krieg A, Bedogni B, LaGory E, Weissman IL, Broome-Powell $\mathrm{M}$ and Giaccia AJ. VHL loss in renal cell carcinoma leads to up-regulation of CUB domain-containing protein 1 to stimulate $\mathrm{PKC} \delta$-driven migration. Proc Natl Acad Sci U S A. 2011; 108(5):19311936.

41. Goswami CP and Nakshatri H. PROGgene: gene expression based survival analysis web application for multiple cancers. J Clin Bioinforma. 2013; 3(1):22.

42. Hoshida Y, Villanueva A, Kobayashi M, Peix J, Chiang DY, Camargo A, Gupta S, Moore J, Wrobel MJ, Lerner J, Reich M, Chan JA, Glickman JN, Ikeda K, Hashimoto M, Watanabe G, Daidone MG, Roayaie S, Schwartz M, Thung S, Salvesen HB, Gabriel S, Mazzaferro V, Bruix J, Friedman SL, Kumada H, Llovet JM and Golub TR. Gene expression in fixed tissues and outcome in hepatocellular carcinoma. N Engl J Med. 2008; 359(19):1995-2004.

43. Joly Y, Dove ES, Knoppers BM, Bobrow M and Chalmers D. Data sharing in the post-genomic world: the experience of the International Cancer Genome Consortium (ICGC) Data Access Compliance Office (DACO). PLoS computational biology. PLoS Comput Biol. 2012; 8(7):e1002549.

44. Gordan JD, Lal P, Dondeti VR, Letrero R, Parekh KN, Oquendo CE, Greenberg RA, Flaherty KT, Rathmell WK, Keith B, Simon MC and Nathanson KL. HIF- $\alpha$ effects on c-Myc distinguish two subtypes of sporadic VHL-deficient clear cell renal carcinoma. Cancer Cell. 2008; 14(6):435446.

45. Sharma MK, Seidlitz EP and Singh G. Cancer cells release glutamate via the cystine/glutamate antiporter. Biochem Biophys Res Commun. 2010; 391(1):91-95.

46. Grewer C, Gameiro A, Zhang Z, Tao Z, Braams S and Rauen T. Glutamate forward and reverse transport: from molecular mechanism to transporter-mediated release after ischemia. IUBMB Life. 2008; 60(9):609-619.

47. Lo M, Wang YZ and Gout PW. The x(c)- cystine/glutamate antiporter: a potential target for therapy of cancer and other diseases. J Cell Physiol. 2008; 215(3):593-602.

48. Timmerman LA, Holton T, Yuneva M, Louie RJ, Padro 
M, Daemen A, Hu M, Chan DA, Ethier SP, van 't Veer LJ, Polyak K, McCormick F and Gray JW. Glutamine sensitivity analysis identifies the $\mathrm{xCT}$ antiporter as a common triple-negative breast tumor therapeutic target. Cancer Cell. 2013; 24(4):450-465.

49. Tanaka K, Watase K, Manabe T, Yamada K, Watanabe M, Takahashi K, Iwama H, Nishikawa T, Ichihara N, Kikuchi T, Okuyama S, Kawashima N, Hori S, Takimoto M and Wada K. Epilepsy and exacerbation of brain injury in mice lacking the glutamate transporter GLT-1. Science. 1997; 276(5319):1699-1702.

50. Zschocke J, Allritz C, Engele J and Rein T. DNA methylation dependent silencing of the human glutamate transporter EAAT2 gene in glial cells. Glia. 2007; 55(7):663-674.

51. Piao Y, Lu L and de Groot J. AMPA receptors promote perivascular glioma invasion via $\beta 1$ integrin-dependent adhesion to the extracellular matrix. Neuro Oncol. 2009; 11(3):260-273.

52. Ripka S, Riedel J, Neesse A, Griesmann H, Buchholz M, Ellenrieder V, Moeller F, Barth P, Gress TM and Michl P. Glutamate receptor GRIA3--target of CUX1 and mediator of tumor progression in pancreatic cancer. Neoplasia. 2010; 12(8):659-667.

53. Bennett LB, Schnabel JL, Kelchen JM, Taylor KH, Guo J, Arthur GL, Papageorgio CN, Shi H and Caldwell CW. DNA hypermethylation accompanied by transcriptional repression in follicular lymphoma. Genes Chromosomes Cancer. 2009; 48(9):828-841.

54. Kostareli E, Holzinger D, Bogatyrova O, Hielscher T, Wichmann G, Keck M, Lahrmann B, Grabe N, Flechtenmacher C, Schmidt CR, Seiwert T, Dyckhoff G, Dietz A, Höfler D, Pawlita M, Benner A, Bosch FX, Plinkert P, Plass C, Weichenhan D and Hess J. HPV-related methylation signature predicts survival in oropharyngeal squamous cell carcinomas. J Clin Invest. 2013; 123(6):2488-2501.

55. Tsibris JC, Maas S, Segars JH, Nicosia SV, Enkemann SA, O'Brien WF and Spellacy WN. New potential regulators of uterine leiomyomata from DNA arrays: the ionotropic glutamate receptor GluR2. Biochem Biophys Res Commun. 2003; 312(1):249-254.

56. Arslan AA, Gold LI, Mittal K, Suen TC, BelitskayaLevy I, Tang MS and Toniolo P. Gene expression studies provide clues to the pathogenesis of uterine leiomyoma: new evidence and a systematic review. Hum Reprod. 2005; 20(4):852-863.

57. Leja J, Essaghir A, Essand M, Wester K, Oberg K, Totterman TH, Lloyd R, Vasmatzis G, Demoulin JB and Giandomenico V. Novel markers for enterochromaffin cells and gastrointestinal neuroendocrine carcinomas. Mod Pathol. 2009; 22(2):261-272.

58. Beretta F, Bassani S, Binda E, Verpelli C, Bello L, Galli R and Passafaro M. The GluR2 subunit inhibits proliferation by inactivating Src-MAPK signalling and induces apoptosis by means of caspase 3/6-dependent activation in glioma cells. Eur J Neurosci. 2009; 30(1):25-34.

59. Herner A, Sauliunaite D, Michalski CW, Erkan M, De Oliveira T, Abiatari I, Kong B, Esposito I, Friess H and Kleeff J. Glutamate increases pancreatic cancer cell invasion and migration via AMPA receptor activation and Kras-MAPK signaling. Int J Cancer. 2011; 129(10):23492359.

60. Li L and Hanahan D. Hijacking the neuronal NMDAR signaling circuit to promote tumor growth and invasion. Cell. 2013; 153(1):86-100.

61. Iwamoto FM, Kreisl TN, Kim L, Duic JP, Butman JA, Albert PS and Fine HA. Phase 2 trial of talampanel, a glutamate receptor inhibitor, for adults with recurrent malignant gliomas. Cancer. 2010; 116(7):1776-1782.

62. Zhang H, Qian DZ, Tan YS, Lee K, Gao P, Ren YR, Rey S, Hammers H, Chang D, Pili R, Dang CV, Liu JO and Semenza GL. Digoxin and other cardiac glycosides inhibit HIF-1 $\alpha$ synthesis and block tumor growth. Proc Natl Acad Sci U S A. 2008; 105(50):19579-19586.

63. Chintala S, Najrana T, Toth K, Cao S, Durrani FA, Pili $\mathrm{R}$ and Rustum YM. Prolyl hydroxylase 2 dependent and Von-Hippel-Lindau independent degradation of hypoxiainducible factor 1 and 2 alpha by selenium in clear cell renal cell carcinoma leads to tumor growth inhibition. BMC Cancer. 2012; 12:293.

64. Xiang L, Gilkes DM, Chaturvedi P, Luo W, Hu H, Takano $\mathrm{N}$, Liang $\mathrm{H}$ and Semenza GL. Ganetespib blocks HIF-1 activity and inhibits tumor growth, vascularization, stem cell maintenance, invasion, and metastasis in orthotopic mouse models of triple-negative breast cancer. J Mol Med (Berl). 2014; 92:151-164.

65. Onnis B, Rapisarda A and Melillo G. Development of HIF-1 inhibitors for cancer therapy. J Cell Mol Med. 2009; 13(9A):2780-2786.

66. Zhang H, Gao P, Fukuda R, Kumar G, Krishnamachary B, Zeller KI, Dang CV and Semenza GL. HIF-1 inhibits mitochondrial biogenesis and cellular respiration in VHLdeficient renal cell carcinoma by repression of C-MYC activity. Cancer Cell. 2007; 11(5):407-420. 